\title{
Occurrence of Cryptosporidium and Giardia and the Relationship between Protozoa and Water Quality Indicators in Swimming Pools
}

\author{
Shumin Xiao ${ }^{1,2, *}$, Pengna Yin', Yan Zhang', Sike $\mathrm{Hu}^{3, * *}$ \\ ${ }^{1}$ School of Environmental and Municipal Engineering, Tianjin Chengjian University, Tianjin 300384, P. R. China; ${ }^{T}$ Tianjin Key Laboratory of Aquatic \\ Science and Technology, Tianjin 300384, P. R. China; ${ }^{3}$ School of Medicine, Nankai University, Tianjin 300071, P. R. China
}

\begin{abstract}
A total of 60 samples were collected from 35 swimming pools in Beijing, China, and the presence of Cryptosporidium and Giardia were investigated. The results showed that $16.7 \%$ and $15.0 \%$ of samples were positive for Cryptosporidium oocyst and Giardia cysts, respectively, with a mean concentration of 0.30 oocysts/10 L and 0.27 cysts/10 L. The oocysts and cysts were found to have higher rates of occurrence in August than in May. Genotyping confirmed the presence of Cryptosporidium hominis, C. parvum, and Giardia assemblages A and B, all of which were associated with human infections. The predominant species/assemblages were C. hominis and Giardia assemblage A. Analyses of the relationships between parasite oocysts/cysts, indicator bacteria, and physical-chemical parameters revealed that there was no correlation between 2 parasites and fecal bacterial indicators, whilst there was a significant correlation between protozoa and urea concentration, which indicates that urea concentration rather than fecal bacterial indicators might be an appropriate index for chlorine-resistant protozoa in swimming pools. This study provides useful information to improve the safety of swimming pool water and deduce the risk of protozoan infections.
\end{abstract}

Key words: Cryptosporidium, Giardia, bacterial indicator, swimming pool, water quality

\section{INTRODUCTION}

Swimming is one of the popular recreational activities worldwide. It offers health and social benefits, and it is suitable for a wide age range of people from children to aged persons. However, health risks for swimmers may arise from exposure to pool water of poor quality [1]. They may suffer from various diseases, such as gastroenteritis caused by bacteria, viruses, or parasites of fecal origin, which may be released by the bathers or, in the case of outdoor pools, by animals, such as birds and rodents [2].

Many studies were carried out to investigate the presence of Cryptosporidium and Giardia in swimming pool water. It was found that $8.1 \%$ of swimming pools in Georgia, USA and $11.8 \%$ in the Netherlands were contaminated with Cryptosporidium and/or Giardia [3,4]. In China, Cryptosporidium and Giardia were

\footnotetext{
- Received 17 January 2017, revised 24 February 2017, accepted 11 March 2017.

*Corresponding author (xiaoshumin@tcu.edu.cn; husike@126.com)

(c) 2017, Korean Society for Parasitology and Tropical Medicine

This is an Open Access article distributed under the terms of the Creative Commons Attribution Non-Commercial License (http://creativecommons.org/licenses/by-nc/4.0) which permits unrestricted non-commercial use, distribution, and reproduction in any medium, provided the original work is properly cited.
}

detected in surface water which was used for drinking water production [5-7], but there was no data available for recreational water.

Several indicators were used to assess the microbiological quality of swimming pool water. Some consider that bacteria from fecal contamination affect the microbial quality of pool waters [8], while others emphasize that microorganisms derived from vomit, mucus, saliva, and skin of bathers rather than fecal contamination contributed to the risk of infection $[9,10]$. Nevertheless, heterotrophic plate count bacteria (HPC), total coliforms (TC), and fecal coliforms were still regarded as the best microorganisms to indicate hygienic conditions $[1,11$, 12]. In China, HPC and TC are applied as the microbial indicators in the Hygienic Standard for Swimming Place [13] and physical-chemical properties, such as urea, free available chlorine, $\mathrm{pH}$, and turbidity are also used in this standard as indicators to predict the quality of the pool water.

Previous studies found that fecal bacterial indicators could well indicate contamination of Cryptosporidium and Giardia in surface water [14-16]. However, there was no data available that bacterial and physical-chemical indicators can be used to indicate contamination of the protozoa in artificially controlled 
water, such as swimming pool waters.

In the present study, the presence and genotype of Cryptosporidium and Giardia in public swimming pools was investigated. The correlations between parasitic pathogens and basic quality of the water such as bacterial indicators, physical-chemical properties were also assessed.

\section{MATERIALS AND METHODS}

\section{Water sampling}

A total of 60 water samples from 35 swimming pools in Beijing, China were collected. The swimming pools were selected at random, and the type of pool was classified based on its location. In May 2015, 27 samples were collected from 27 pools. In August, 25 pools were re-sampled and another 8 pools were sampled, amounting to 33 samples. All of the sampling was conducted in the evening when the swimmer numbers usually reached the highest point of the day. The sampling point was at the central area of each pool, in order to avoid the hydraulically stagnant zone.

\section{Detection of parasitic pathogens}

Cryptosporidium oocyst and Giardia cyst concentrations were measured following the previously described method, including filtration, flotation, labeling with monoclonal antibody, and microscopic analysis [17]. Briefly, 10-liter water samples were filtered through membrane filters of $142 \mathrm{~mm}$ diameter with a $1.0 \mu \mathrm{m}$ pore size. After filtration, the membrane filter was dissolved in acetone solutions to recover oocysts/cysts. Then, the recovered oocysts/cysts were separated from other particulate materials by flotation on Percoll-sucrose gradients. Finally, the pellets from the purification were stained with a combined fluorescein isothiocyanate (FITC) conjugated antiCryptosporidium and anti-Giardia monoclonal antibodies (Waterborne Inc., New Orleans, Louisiana, USA) and examined microscopically for the detection of Cryptosporidium oocysts and Giardia cysts. This method permitted a mean recovery of $41.3 \%$ for initial recovery tests, which meets the acceptance criteria of the US Environmental Protection Agency (USEPA) Method 1623 (24-100\% recovery) [17].

To determine the species/genotypes of the protozoa, another 10-liter samples from each pool, in the second campaign, were collected and concentrated. Genomic DNA was extracted from each Percoll-sucrose flotation-purified pellet by using a FastDNA SPIN kit for soil (MP Biomedicals, Illkirch, France), according to the manufacturer's instructions, and eluted in 50 $\mu \mathrm{l}$ of reagent-grade water as described previously [17]. Cryptosporidium was genotyped by a nested PCR amplification of a 435-bp fragment of the small subunit (SSU) rRNA locus, and Giardia assemblages were identified by using another nested PCR to amplify of a 292-bp fragment of Giardia SSU rRNA gene. Primers and amplification conditions were employed as described by Plutzer et al. [18]. All positive secondary PCR products were purified and cloned. Clones were sent to Beijing Augct Co., Ltd. for sequencing using ABI 3730 automated DNA sequencer (BigDye Terminator Chemistry, Applied Biosystems, Foster City, California, USA). Nucleotide sequences obtained in the study, with reference sequences downloaded from the GenBank database, were aligned using the Clustal W programs and analyzed to determine Cryptosporidium species and Giardia assemblages using phylogenetic trees.

\section{Analyses of bacterial indicator and physical-chemical quality}

Colony counts and 5-tube most probable numbers (MPN) procedure was used, respectively, to enumerate HPC and TC according to Chinese standard examination method for drinking water-microbiological parameters [19]. Briefly, a 10-fold serial dilution of each sample was carried out. For HPC, $1.0 \mathrm{ml}$ each of serial dilutions were inoculated in sterile nutrient agar plates and incubated at $36^{\circ} \mathrm{C}$ for $48 \mathrm{hr}$, counting colonies as they developed. While for TC, another $1.0 \mathrm{ml}$ each of serial dilutions were transferred to 5 tubes of lactose peptone broth $(10.0 \mathrm{ml})$ with inverted Durham tubes, which were then incubated at $37^{\circ} \mathrm{C}$ for $24 \pm 2 \mathrm{hr}$. All positive presumptive tubes that demonstrated an acidic reaction or gas production were submitted to the confirmed phase with total coliform test by using eosin methylene blue agar medium according to the above standard [19]. The physical-chemical quality of the water in terms of turbidity, $\mathrm{pH}$, urea, and free residual chlorine was on site measured for each sample with portable photometer.

\section{Statistical analysis}

Data were tabulated and compared with local guidelines [13]. The chi-square test was used to evaluate possible significant differences in the seasonal pattern of the prevalence of Cryptosporidium and Giardia. Whereas the concentrations of the parasites in different time points were compared using pairedsamples t-test, the association between parasite concentrations, the concentration of microbiological indicators, and physical- 
chemical properties was correlated using the nonparametric Spearman's correlation 2-tailed test. Differences with $P$-values of $<0.05$ were defined as being statistically significant. All statistical tests were performed using PASW Statistics 18 computer software package.

\section{RESULTS}

\section{Occurrence and genotyping of Cryptosporidium oocyst and Giardia cyst in water samples}

Of the 60 swimming pool water samples collected, 10 (16.7\%) were positive for Cryptosporidium and 9 (15.0\%) were positive for Giardia. The mean concentration of Cryptosporidium and Giardia were 0.30 oocysts/10 L and 0.27 cysts/10 L, respectively (Table 1). Although the detection percentages of the cysts of Giardia changed little (14.8-15.2\%) for the 2 sampling campaigns (chi-square, $P>0.05$ ), the positive rate of Cryptosporidium oocyst was higher in August (24.2\%) than in May (7.4\%).

It was revealed that $2 / 5$ of outdoor pools, $3 / 6$ of school pools, $3 / 5$ of community pools, $2 / 7$ of hotel pools, and $3 / 6$ of commercial pools were positive for Cryptosporidium, Giardia, or both (data not shown). However, no oocysts or cysts were detected in any of the sampled waters from 6 bath pools. The counts of parasites ranged from 0 to 4 oocysts and 0 to 3 cysts per $10 \mathrm{~L}$ (Table 1). A higher detection percentage of both parasites were found in samples from outdoor swimming pools than that from indoor pools. Nevertheless, the concentration of oocysts or cysts in the samples was at the same level.

DNA sequencing of PCR products revealed the presence of the following 2 species of Cryptosporidium and 2 Giardia assem- blages; C. hominis, C. parvum, and Giardia assemblage A and B. The most common Cryptosporidium species and Giardia assemblage were $C$. hominis and Giardia assemblage A, which were found in 5 and 3 positive samples, respectively (Table 2).

\section{Fecal bacterial indicator and physical-chemical analyses}

The results in Table 3 show the average values, median values, and ranges of the fecal bacterial indicator and physical-chemical parameters of swimming pool water. HPC and TC were found positive in 30 and 22 out of 60 samples, respectively. However, only in 1 commercial pool and 1 hotel pool, the values of bacterial indicator violated the guideline limits (HPC, $>1,000 \mathrm{CFU} / \mathrm{ml}$ or TC, $>18 \mathrm{MPN} / \mathrm{L}$ ) [13].

As for urea, 22/60 of samples have a value over $3.5 \mathrm{mg} / \mathrm{L}$. It was obvious that all the surveyed turbidity values (0.1-0.8 NTU) in swimming pools were consistent with the standard (not more than 5 NTU) [13]. Similarly, no pH value was out of the

Table 2. Distribution of Cryptosporidium species and Giardia assemblage in water samples collected from swimming pools in August 2015

\begin{tabular}{|c|c|c|}
\hline Sample location & $\begin{array}{l}\text { Detection } \\
\text { rate }\end{array}$ & Type of parasites (no. of samples) \\
\hline Outdoor pool & $2 / 5$ & C. parvum (1); Giardia assemblage A (1) \\
\hline School pool & $3 / 6$ & $\begin{array}{l}\text { C. hominis and Giardia assemblage A (1); } \\
\text { C. hominis (2) }\end{array}$ \\
\hline Community pool & $2 / 4$ & C. hominis (1); Giardia assemblage B (1) \\
\hline Hotel pool & $1 / 6$ & C. hominis (1) \\
\hline Bath pool & $0 / 6$ & \\
\hline Commercial pool & $2 / 6$ & C. hominis (1); Giardia assemblage A (1) \\
\hline Total & $10 / 33$ & $\begin{array}{l}\text { C. parvum (1); C. hominis (6); Giardia as- } \\
\text { semblage A (3) and B (1) }\end{array}$ \\
\hline
\end{tabular}

Table 1. Occurrence of Cryptosporidium oocysts and Giardia cysts in water samples collected from swimming pools in Beijing, China

\begin{tabular}{|c|c|c|c|c|c|c|c|c|c|}
\hline & \multirow{2}{*}{$\begin{array}{l}\text { No. of } \\
\text { sample }\end{array}$} & \multicolumn{4}{|c|}{ Cryptosporidium (no. of oocysts/10 L) } & \multicolumn{4}{|c|}{ Giardia (no. of cysts/10 L) } \\
\hline & & $\begin{array}{c}\text { No. of } \\
\text { positive (\%) }\end{array}$ & Mean \pm SD & Min.-Max. & $95 \% \cup C L^{a}$ & $\begin{array}{c}\text { No. of } \\
\text { positive (\%) }\end{array}$ & Mean \pm SD & Min.-Max. & $95 \% \mathrm{UCL}^{2}$ \\
\hline \multicolumn{10}{|l|}{ Time of sampling } \\
\hline May 2015 & 27 & $2(7.4)$ & $0.07 \pm 0.27$ & $0-1$ & 0.20 & $4(14.8)$ & $0.22 \pm 0.64$ & $0-3$ & 0.50 \\
\hline August 2015 & 33 & $8(24.2)$ & $0.48 \pm 1.00$ & $0-4$ & 0.85 & $5(15.2)$ & $0.30 \pm 0.77$ & $0-3$ & 0.58 \\
\hline \multicolumn{10}{|l|}{ Pool type } \\
\hline Outdoor pool & 5 & $2(40.0)$ & $0.60 \pm 0.89$ & $0-2$ & 1.50 & $2(40.0)$ & $0.80 \pm 1.30$ & $0-3$ & 2.00 \\
\hline School pool & 12 & $4(33.3)$ & $0.58 \pm 1.00$ & $0-3$ & 1.17 & $2(16.7)$ & $0.25 \pm 0.62$ & $0-2$ & 0.67 \\
\hline Community pool & 9 & $1(11.1)$ & $0.22 \pm 0.67$ & $0-2$ & 0.80 & $2(22.2)$ & $0.33 \pm 0.71$ & $0-2$ & 0.88 \\
\hline Hotel pool & 13 & $1(7.7)$ & $0.15 \pm 0.38$ & $0-1$ & 0.38 & $1(7.7)$ & $0.23 \pm 0.83$ & $0-3$ & 0.75 \\
\hline Bath pool & 12 & $0(0.0)$ & $0.00 \pm 0.00$ & $0-0$ & 0.00 & $0(0.0)$ & $0.00 \pm 0.00$ & $0-0$ & 0.00 \\
\hline Commercial pool & 9 & 2 (22.2) & $0.44 \pm 1.33$ & $0-4$ & 1.45 & $2(22.2)$ & $0.33 \pm 0.71$ & $0-2$ & 0.80 \\
\hline Total & 60 & $10(16.7)$ & $0.30 \pm 0.79$ & $0-4$ & 0.50 & $9(15.0)$ & $0.27 \pm 0.71$ & $0-3$ & 0.45 \\
\hline
\end{tabular}

aUCL, upper confidence limit which was calculated based on 1,000 bootstrap samples using PASW statistics 18 software. 
Table 3. Fecal indicator bacteria and physical-chemical parameters of water samples collected from swimming pools in Beijing, China

\begin{tabular}{|c|c|c|c|c|c|c|c|}
\hline Pool type & Statistics & $\mathrm{HPC}^{\mathrm{a}}$ (CFU/ml) & $\mathrm{TC}^{\mathrm{b}}$ (MPN/L) & Urea (mg/L) & Turbidity (NTU) & $\mathrm{pH}$ & Free chlorine (mg/L) \\
\hline \multirow[t]{3}{*}{ Outdoor pool } & Mean \pm SD & $232.0 \pm 228.0$ & $3.0 \pm 4.1$ & $3.7 \pm 3.3$ & $0.3 \pm 0.1$ & $7.3 \pm 0.2$ & $0.4 \pm 0.1$ \\
\hline & Median & 140.0 & 3.5 & 3.7 & 0.3 & 7.4 & 0.4 \\
\hline & Range & $50-600$ & $<3-8$ & $0.3-7.5$ & $0.2-0.4$ & $7.1-7.5$ & $0.3-0.5$ \\
\hline \multirow[t]{3}{*}{ School pool } & Mean \pm SD & $90.8 \pm 199.7$ & $2.5 \pm 3.8$ & $2.0 \pm 1.6$ & $0.3 \pm 0.1$ & $7.2 \pm 0.2$ & $0.5 \pm 0.1$ \\
\hline & Median & 8.6 & 1.9 & 1.1 & 0.3 & 7.2 & 0.5 \\
\hline & Range & $<1-700$ & $<3-12$ & $0.4-4.3$ & $0.2-0.6$ & $7.0-7.4$ & $0.3-0.8$ \\
\hline \multirow[t]{3}{*}{ Community pool } & Mean \pm SD & $13.3 \pm 40.0$ & $0.3 \pm 1.0$ & $2.6 \pm 2.4$ & $0.4 \pm 0.2$ & $7.2 \pm 0.1$ & $0.8 \pm 0.3$ \\
\hline & Median & 13.3 & 0.3 & 1.6 & 0.5 & 7.1 & 0.6 \\
\hline & Range & $<1-120$ & $<3-3$ & $0.2-6.5$ & $0.1-0.8$ & $7.1-7.4$ & $0.5-1.5$ \\
\hline \multirow[t]{3}{*}{ Hotel pool } & Mean \pm SD & $197.7 \pm 356.1$ & $4.6 \pm 7.5$ & $1.7 \pm 1.6$ & $0.3 \pm 0.2$ & $7.2 \pm 0.2$ & $0.4 \pm 0.2$ \\
\hline & Median & 30.0 & 3.0 & 1.4 & 0.3 & 7.2 & 0.4 \\
\hline & Range & $<1-1,100$ & $<3-27$ & $0.1-4.3$ & $0.1-0.6$ & $7.0-7.6$ & $<0.02-0.6$ \\
\hline \multirow[t]{3}{*}{ Bath pool } & Mean \pm SD & $63.3 \pm 119.9$ & $0.9 \pm 1.7$ & $2.3 \pm 1.8$ & $0.3 \pm 0.2$ & $7.2 \pm 0.1$ & $0.7 \pm 0.4$ \\
\hline & Median & 35.6 & 0.9 & 2.8 & 0.3 & 7.1 & 0.6 \\
\hline & Range & $<1-400$ & $<3-4$ & $0.3-5.7$ & $0.1-0.7$ & $7.0-7.4$ & $0.3-1.3$ \\
\hline \multirow[t]{3}{*}{ Commercial pool } & Mean \pm SD & $297.8 \pm 517.3$ & $5.0 \pm 9.8$ & $2.4 \pm 2.1$ & $0.4 \pm 0.2$ & $7.2 \pm 0.2$ & $0.4 \pm 0.2$ \\
\hline & Median & 80.0 & 2.0 & 0.9 & 0.4 & 7.2 & 0.5 \\
\hline & Range & $<1-1500$ & $<3-30$ & $0.4-5.8$ & $0.1-0.7$ & $7.0-7.6$ & $<0.02-0.7$ \\
\hline \multirow[t]{3}{*}{ All types } & Mean \pm SD & $139.7 \pm 292.1$ & $2.7 \pm 5.7$ & $2.3 \pm 2.0$ & $0.3 \pm 0.2$ & $7.2 \pm 0.2$ & $0.6 \pm 0.3$ \\
\hline & Median & 9.4 & 1.5 & 1.5 & 0.3 & 7.2 & 0.5 \\
\hline & Range & $<1-1,500$ & $<3-30$ & $0.1-7.5$ & $0.1-0.8$ & $7.0-7.6$ & $<0.02-1.5$ \\
\hline
\end{tabular}

aHPC, heterotrophic plate count.

${ }^{\mathrm{b}} \mathrm{TC}$, total coliform.

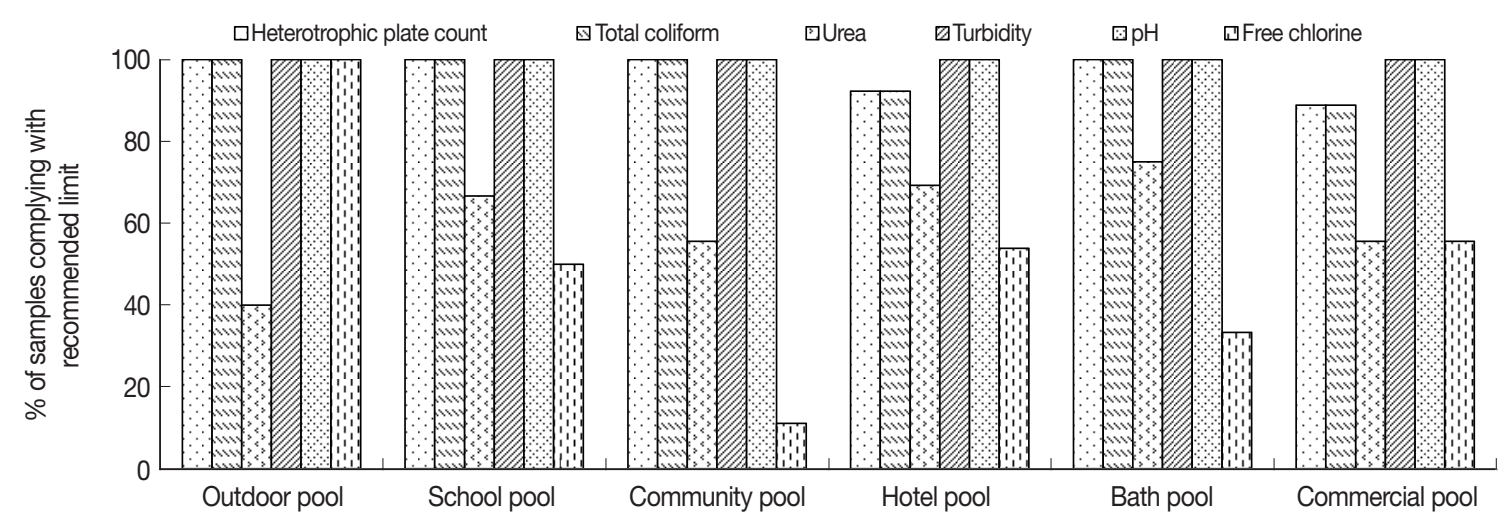

Fig. 1. Percentage of quality indicator in the swimming pool waters complying with the Chinese Hygienic Standard for Swimming Place recommended limits.

standard range (6.5-8.5) (Fig. 1). Surprisingly, nearly a half samples (29/60) contained free residual chlorine exceeding the $0.5 \mathrm{mg} / \mathrm{L}$ limit, and only 3 samples were less than $0.3 \mathrm{mg} /$ $\mathrm{L}$ as reference to the allowable range $(0.3-0.5 \mathrm{mg} / \mathrm{L})$ (Fig. 1).

\section{Relation between microbial quality and physical-chemical properties}

Nonparametric Spearman's correlation 2-tailed test was used to assess the relation between parasitic pathogens, bacterial indicators, and physical-chemical properties. Statistical analysis showed a strong correlation between parasites and urea, but no correlation between parasites and bacterial indices (i.e., HPC and TC). Alternately, a positive correlation of bacterial indicators with $\mathrm{pH}$ and a negative correlation with free chlorine were found. Turbidity did not correlate to any other parameters (Table 4).

\section{DISCUSSION}

Cryptosporidium and Giardia were common findings in recre- 
Table 4. Correlations between parasitic pathogens, bacterial indicators, and physical-chemical parameters in water from different type of swimming pools in Beijing, China

\begin{tabular}{lcccccccc}
\hline & $\begin{array}{c}\text { Crypto- } \\
\text { sporidium }\end{array}$ & Giardia & $\mathrm{HPC}^{\mathrm{a}}$ & $\mathrm{TC}^{\mathrm{b}}$ & Urea & Turbidity & $\mathrm{pH}$ & Free chlorine \\
\hline Crypto-sporidium & - & $0.282^{\mathrm{c}}$ & 0.163 & 0.184 & $0.569^{\mathrm{d}}$ & -0.139 & 0.080 & -0.124 \\
Giardia & $0.282^{\mathrm{c}}$ & - & 0.012 & 0.009 & $0.343^{\mathrm{d}}$ & 0.060 & -0.072 & 0.029 \\
$\mathrm{HPC}^{\mathrm{a}}$ & 0.163 & 0.012 & - & $0.829^{\mathrm{d}}$ & 0.251 & 0.039 & $0.642^{\mathrm{d}}$ & $-0.859^{\mathrm{d}}$ \\
$\mathrm{TC}^{\mathrm{b}}$ & 0.184 & 0.009 & $0.829^{\mathrm{d}}$ & - & 0.223 & 0.034 & $0.603^{\mathrm{d}}$ & $-0.759^{\mathrm{d}}$ \\
Urea $_{\text {Turbidity }}$ & $0.569^{\mathrm{d}}$ & $0.343^{\mathrm{d}}$ & 0.251 & 0.223 & - & 0.104 & 0.109 & -0.138 \\
pH & -0.139 & 0.060 & 0.039 & 0.034 & 0.104 & - & 0.009 & 0.110 \\
Free chlorine & 0.080 & -0.072 & $0.642^{\mathrm{d}}$ & $0.603^{\mathrm{d}}$ & 0.109 & 0.009 & - & 0.157 \\
\hline
\end{tabular}

aHPC, heterotrophic plate count.

${ }^{\mathrm{b} T \mathrm{TC}}$, total coliform.

${ }^{c} P<0.05$ and ${ }^{d} P<0.01$ by Spearman's correlation coefficient (2-tailed test).

ation water, especially in swimming pool waters, which often caused outbreaks $[3,4,20,21]$. In the present study, 13/35 (37.1\%) of swimming pools were tested positive for Cryptosporidium $(14.3 \%)$, Giardia (14.3\%) or both (8.6\%). Similar contamination rates were reported from non-outbreak-related pools in other countries. Studies in Italy found that 2/7 (28.6\%) of surveyed pools were positive for both Cryptosporidium and Giardia [22], and 4/10 (40\%) of pools were positive for either parasite [23]. One or both parasites were found in $8.1 \%(13 / 160)$ of swimming pools in the United States [3] and 11.8\% in the Netherlands [4], while in Greece no oocysts or cysts were found in 5 swimming pools [12]. Recently, Cryptosporidium oocysts and/ or Giardia cysts were detected in 10\% of samples from Egyptian swimming pools [2] and 3 out of 37 swimming pools in Belgium [24].

Relatively low Cryptosporidium concentrations (0.1-0.4 oocysts/L for positive sample) were found in different types of swimming pools in this study. Similar oocyst counts were obtained in swimming pools in Belgium, Egypt, and the Netherlands $[2,4,24]$. On the other hand, in these studies, Giardia cyst counts were usually higher than Cryptosporidium oocyst counts. However, in the present study, the counts of Giardia (0.1-0.3 cyst/L for positive sample) was similar to that of Cryptosporidium.

The occurrences of Cryptosporidium oocysts and Giardia cysts were seasonal, which were more frequently detected in August than in May. This may be due to the higher density in swimmer, since August is the hottest month of the year in Beijing [25]. Similar results were found in Atlanta, Georgia, USA with higher protozoan occurrences in the high dense crowds pool [3]. Shields et al. [3] also revealed that the positive parasite prevalence was higher in pools frequented by children and adults than in pools designated for adults only. The results coincided with those from our study that a high rate of Cryptosporidium positive samples were found in school pools. It should be noted that no oocyst or cyst detection in any of bath pools in this study might be attributed to low dense swimmers, since few people in summer visited the bathing centre, where they incline to have bath other than swimming.

In China, animals, including pets, usually are not allowed to access to swimming pools. As expected, all the detected species of Cryptosporidium (i.e., C. hominis and C. parvum) and Giardia assemblages were associated with human infections. This indicates that anthroponotic transmission is important in cryptosporidiosis and giardiasis epidemiology in the studied area. Similar results were obtained by other authors, who reported that $C$. hominis and Giardia assemblage A were the predominant species/assemblages of the protozoa both in humans [26] and urban wastewaters [27] in China.

Bacterial and physical-chemical properties are conventional indicators applied to monitor water quality. Considering that both Cryptosporidium and Giardia are fecal-derived protozoa, fecal indicator bacteria could well indicate the protozoan contamination $[15,16]$. However, in this study, only 2 out of 35 pools did not meet the standard for bacterial indicator [13], while 13/35 of pools were contaminated with Cryptosporidium or Giardia. The low rate of violation of bacterial indicator did not indicate a low occurrence of Cryptosporidium or Giardia. It was well known that application of disinfection with chlorine has been widely used in China and many other countries to control microbial contamination in swimming pools. More than a half (32/60) of water samples were found with unqualified free chlorine, and most (29/32) of them were unqualified 
because of their high chlorine concentration (Fig. 1). This finding was different from the results obtained from other countries where most of unacceptable samples were associated with lower free chlorine value [28-30]. Free chlorine at proper disinfection levels can kill most bacteria in a short time, while Giardia and Cryptosporidium are moderately even highly resistant to both environmental stress and chlorine [31]. This may be the reason why indicator bacteria (i.e., HPC or TC) were not associated with protozoa in the present study. Therefore, in the chlorine-treated water, including swimming pool waters, bacterial indicator is an inappropriate index for Cryptosporidium or Giardia.

It was interesting that Cryptosporidium and Giardia were tightly related to urea in this study. Urea in swimming pool mainly comes from urine and sweat of bathers [1]. It was estimated that 25-30 ml/bather of urine was released into swimming pools [32], and urea be released at an average of $37.1 \mathrm{mg} /$ bather during 30 min of exercise [33]. During urination, feces in the anus are prone to discharged, and this would raise the contamination of Cryptosporidium and/or Giardia. This may be the reason why urea was close touch with the protozoa. The analyses of the parasite genotypes also showed that the contamination of Cryptosporidium and/or Giardia is from humans. Therefore, analysis of urea in swimming pool waters is proposed as a simple and effective method to monitor fresh man-made water pollution [34].

In conclusion, Cryptosporidium oocysts and/or Giardia cysts were present in different types of swimming pool waters in Beijing, China, with a more frequent occurrence in August than in May. Detection of species/genotype revealed that $C$. hominis and Giardia assemblage A were the predominant species/assemblages, and anthroponotic transmission is an important route of the protozoan diseases. Fecal bacterial indicator was not an appropriate index to monitor the contamination of Cryptosporidium or Giardia in chlorine-treated water, including swimming pool waters. The close relation between the protozoa and urea indicated that urea might be a suitable indicator for Cryptosporidium and Giardia in swimming pools.

\section{ACKNOWLEDGMENTS}

This work was supported by grants from the National Natural Science Foundation of China (no. 51278174), the Natural Science Foundation of Tianjin City (no. 15JCQNJC44000), and the Research Found of Tianjin Key Laboratory of Aquatic
Science and Technology (no. TJKLAST-PT-2014-4).

\section{CONFLICT OF INTEREST}

The authors declare no conflict of interest.

\section{REFERENCES}

1. WHO. Guidelines for Safe Recreational Water Environments, Vol. 2. Swimming Pools and Similar Environments. Geneva, Switzerland. World Health Organization. 2006.

2. Abd El-Salam MM. Assessment of water quality of some swimming pools: a case study in Alexandria, Egypt. Environ Monit Assess 2012; 184: 7395-7406.

3. Shields JM, Gleim ER, Beach MJ. Prevalence of Cryptosporidium spp. and Giardia intestinalis in swimming pools, Atlanta, Georgia. Emerg Infect Dis 2008; 14: 948-950.

4. Schets FM, Engels GB, Evers EG. Cryptosporidium and Giardia in swimming pools in the Netherlands. J Water Health 2004; 2: 191-200

5. Xiao S, An W, Chen Z, Zhang D, Yu J, Yang M. The burden of drinking water-associated cryptosporidiosis in China: the large contribution of the immunodeficient population identified by quantitative microbial risk assessment. Water Res 2012; 46: 4272-4280.

6. Hu Y, Feng Y, Huang C, Xiao L. Occurrence, source, and human infection potential of Cryptosporidium and Enterocytozoon bieneusi in drinking source water in Shanghai, China, during a pig carcass disposal incident. Environ Sci Technol 2014; 48: 1421914227.

7. Feng Y, Zhao X, Chen J, Jin W, Zhou X, Li N, Wang L, Xiao L. Occurrence, source, and human infection potential of Cryptosporidium and Giardia spp. in source and tap water in Shanghai, China. Appl Environ Microbiol 2011; 77: 3609-3616.

8. Erdinger L, Kirsch F, Sonntag HG. Potassium as an indicator of anthropogenic contamination of swimming pool water. Zentralbl Hyg Umweltmed 1997; 200: 297-308.

9. Fazlzadeh M, Sadeghi H, Bagheri P, Poureshg Y, Rostami R. Microbial quality and physical-chemical characteristics of thermal springs. Environ Geochem Health 2016; 38: 413-422.

10. Esterman A, Roder DM, Cameron AS, Robinson BS, Walters RP, Lake JA, Christy PE. Determinants of the microbiological characteristics of South Australian swimming pools. Appl Environ Microbiol 1984; 47: 325-328.

11. Casanovas-Massana A, Blanch AR. Characterization of microbial populations associated with natural swimming pools. Int J Hyg Environ Health 2013; 216: 132-137.

12. Papadopoulou C, Economou V, Sakkas H, Gousia P, Giannakopoulos X, Dontorou C, Filioussis G, Gessouli H, Karanis P, Leveidiotou S. Microbiological quality of indoor and outdoor swimming pools in Greece: investigation of the antibiotic resistance of the bacterial isolates. Int J Hyg Environ Health 2008; 
211: 385-397.

13. GB/9667-1996. Hygienic Standard for Swimming Place. Standards Press of China: Beijing, China, 1997.

14. Xiao G, Qiu Z, Qi J, Chen JA, Liu F, Liu W, Luo J, Shu W. Occurrence and potential health risk of Cryptosporidium and Giardia in the Three Gorges Reservoir, China. Water Res 2013; 47: 24312445.

15. Lipp EK, Farrah SA, Rose JB. Assessment and impact of microbial fecal pollution and human enteric pathogens in a coastal community. Mar Pollut Bull 2001; 42: 286-293.

16. Touron A, Berthe T, Gargala G, Fournier M, Ratajczak M, Servais $P$, Petit F. Assessment of faecal contamination and the relationship between pathogens and faecal bacterial indicators in an estuarine environment (Seine, France). Mar Pollut Bull 2007; 54: 1441-1450.

17. Xiao S, An W, Chen Z, Zhang D, Yu J, Yang M. Occurrences and genotypes of Cryptosporidium oocysts in river network of southern-eastern China. Parasitol Res 2012; 110: 1701-1709.

18. Plutzer J, Karanis P, Domokos K, Torokne A, Marialigeti K. Detection and characterisation of Giardia and Cryptosporidium in Hungarian raw, surface and sewage water samples by IFT, PCR and sequence analysis of the SSUrRNA and GDH genes. Int J Hyg Environ Health 2008; 211: 524-533.

19. GB/T5750.12-2006. Standard Examination Methods for Drinking Water-microbiological Parameters. Beijing, China. Standards Press of China. 2007.

20. Takagi M, Toriumi H, Endo T, Yamamoto N, Kuroki T. An outbreak of cryptosporidiosis associated with swimming pools. Kansenshogaku Zasshi 2008; 82: 14-19.

21. Coetzee N, Edeghere O, Orendi J, Chalmers R, Morgan L. A swimming pool-associated outbreak of cryptosporidiosis in Staffordshire, England, October to December 2007. Euro Surveill 2008; 13: pii-19028.

22. Oliveri R, Di Piazza F, Marsala B, Cerame G, Firenze A, Di Benedetto MA. Occurrence of Giardia cysts and Cryptosporidium oocysts in swimming pools in the province of Palermo, Italy. Ann Ig 2006; 18: 367-374.

23. Bonadonna L, Briancesco R, Magini V, Orsini M, Romano-Spica $\mathrm{V}$. A preliminary investigation on the occurrence of protozoa in swimming pools in Italy. Ann Ig 2004; 16: 709-719.

24. Ehsan A, Geurden T, Casaert S, Paulussen J, De Coster L, Schoemaker T, Chalmers R, Grit G, Vercruysse J, Claerebout E. Occurrence and potential health risk of Cryptosporidium and Giardia in different water catchments in Belgium. Environ Monit Assess 2015; $187: 6$.

25. Sun Z, Xu W, Song G. Analysis on sanitary conditions of swimming pool water in Dongcheng District of Beijing in 2013. Occupation and Health 2015; 31: 656-657 (in Chinese).

26. Wang R, Zhang X, Zhu H, Zhang L, Feng Y, Jian F, Ning C, Qi M, Zhou Y, Fu K, Wang Y, Sun Y, Wang Q, Xiao L. Genetic characterizations of Cryptosporidium spp. and Giardia duodenalis in humans in Henan, China. Exp Parasitol 2011; 127: 42-45.

27. Liu A, Ji H, Wang E, Liu J, Xiao L, Shen Y, Li Y, Zhang W, Ling H. Molecular identification and distribution of Cryptosporidium and Giardia duodenalis in raw urban wastewater in Harbin, China. Parasitol Res 2011; 109: 913-918.

28. Rabi A, Khader Y, Alkafajei A, Aqoulah AA. Sanitary conditions of public swimming pools in Amman, Jordan. Int J Environ Res Public Health 2007; 4: 301-306.

29. Abdou MH, Akel MM, El-Shal WI, El-Naggar AS. Study of the environmental health aspects of swimming pools in Alexandria City. J Egypt Public Health Assoc 2005; 80: 263-296.

30. Bilajac L, Lušić DV, Jelinić JD, Rukavina T. Microbiological and chemical indicators of water quality in indoor hotel swimming pools before and after training of swimming pool operators. J Water Health 2012; 10: 108-115.

31. WHO. Risk assessment of Cryptosporidium in drinking water. Geneva, Switzerland. World Health Organization. 2009.

32. Gunkel K, Jessen HJ. The problem of urea in bathing water. Z Gesamte Hyg 1988; 34: 248-250.

33. Keuten MGA, Peters MCFM, Daanen HAM, de Kreuk MK, Rietveld LC, van Dijk JC. Quantification of continual anthropogenic pollutants released in swimming pools. Water Res 2014; 53: 259270.

34. Khramov VA, Gizzatova GL. Urea as an indicator of anthropogenic pollution of water of swimming pools. Gig Sanit 2006; 3: 3-4. 
